\title{
PENINGKATAN PEMBANGUNAN EKONOMI MELALUI POLITIK HUKUM OMNIBUS LAW
}

\author{
Kinaria Afriani, Derry Angling Kesuma, Husnaini \\ Sekolah Tinggi Ilmu Hukum Sumpah Pemuda \\ riakirey.82@gmail.com,kesumaderry@gmail.com
}

\begin{abstract}
Abstrak
Omnibus Law sebagai upaya Pemerintah dalam meningkatkan pembangunan ekonomi di Indonesia dan meningkatkan kesejahteraan seluruh rakyat Indonesia dalam perumusan maupun implementasinya harus berimbang dalam tataran efektivitas dan akuntabilitas dengan memperhatikan aspek yuridis, politik, sosiologi dan ekonomi.

\section{Kata kunci: Pembangunan Ekonomi, Politik Hukum, Omnibus Law}

\section{Abstract}

Omnibus Law, the Government's efforts to improve economic development in Indonesia and improve the welfare of all Indonesian people in its formulation and implementation must be balanced in the level of effectiveness and accountability by taking into account juridical, political, sociological and economic aspects.
\end{abstract}

\section{Keywords: Economic Development, Political Law, Omnibus Law}

\section{A. Latar Belakang}

Secara historis, praktik penerapan Omnibus Law banyak diterapkan diberbagai negara Common Law System, dengan tujuan untuk memperbaiki regulasi dinegaranya masing-masing dalam rangka meningkatkan iklim dan daya saing investasi. Secara umum Omnibus Law belum populer di Indonesia. ${ }^{1}$

Omnibus Law merupakan metode yang digunakan untuk mengganti dan /atau mencabut beberapa materi hukum dalam berbagai undang-undang, dimana konsekuensi dengan penerapan Omnibus Law adalah :

1)UU existing masih tetap berlaku, kecuali sebagian pasal (materi

\footnotetext{
${ }^{1}$ Dhaniswara $\quad$ K. Harjono, KonsepOmnibusLawDitinjauDari UndangUndangNo.12Tahun2011TentangPembentuk anPeraturanPerundangUndangan,

JurnalHukum:HukumUntukMengaturDanMelindung iMasyarakat,

FakultasHukumUniversitasKristenIndonesia, Jakarta 2020, hlm. 98.
}

hukum) yangtelah diganti atau dinyatakan tidak berlaku;

2)UUexisting tidak diberlakukan lagi, apabila pasal (materi hukum) yang diganti atau dinyatakan

Gagasan konsep Omnibus Law pertama kali di sampaikan Presiden Jokowi pada pidato pelantikannya pada Sidang Paripurna MPRRI tanggal 20 Oktober 2019 yang dalam pidatonya tersebut Presiden Jokowi mengatakan:"dalam5 (lima) tahun kedepan yang akan dikerjakan antara lain :

1) Membangun SDM yang pekerja keras;

2) Pemerintahakan mengajak DPR untuk menerbitkan UU Cipta Lapangan Kerja yang menjadi Omnibus Law untuk merevisi puluhan Undang Undang yang menghambat penciptaan lapangan kerja danyang menghambat pengembangan UM$\mathrm{KM}$;

3) Investasi untuk penciptaaan lapangan kerja harus diprioritaskan dan prosedur yang panjang harus dipotong". 
Menurut Presiden Jokowi, melalui Omnibus Law, akan dilakukan penyederhanaan kendala regulasi yang saat ini berbelit Panjang. ${ }^{2}$

Merujuk pada gagasan Omnibus Law tersebut, Presiden Jokowi akan merampingkan regulasi dengan membentuk dua UU, yaitu UU Cipta Lapangan Kerja dan UU Pemberdayaan Usaha Mikro Kecil dan Menengah (UMKM). Pembentukan UU ini sekaligus memangkas puluhan regulasi yang berkaitan dengan ketenagakerjaan dan pemberdayaan UMKM. ${ }^{3}$ Penyederhanaan sekitar puluhan UU menjadi kompilasi satu UU baru yang akan dilakukan oleh pemerintah merupakan konsep yangdikenal dengan Omnibus Law.Dalam hal ini dilakukan pembentukan UU baru dengan konsep Omnibus Law yang menurut Mirza Satria Buana, ${ }^{4}$ ahli hukum tata negara Lambung Mangkurat dianggap sebagai UU sapu jagat yang dapat digunakan untuk mengganti beberapa norma hukum dalam beberapa undang-undang. Secara harfiah omnibus berasal dari Bahasa Latin omnis yang berarti "banyak".

Dalam Black Law Dictionary Ninth Editions Bryan A. Garner, omnibus relating to or dealing with numerousobject or item at once; including many thing or having varius purposes. Dari segi hukum kata omnibus lazim disandingkan dengan kata law (hukum) atau bill (pajak/tagihan) yang berarti suatu peraturan yang dibuat berdasarkan hasil kompilasi beberapa aturan dengan substansi dan tingkatan berbeda. Sebenarnya praktik penggunaan Omnibus Law telah banyak dilakukan oleh banyak

\footnotetext{
${ }^{2}$ https://kompas.com/tren/read/2019/10/22/apa -itu-omnibus-law.diakses pada tanggal 28 April 2021.

${ }^{3}$ Sulasi Rongiyati, Menata Regulasi Pemberdayaan UMKM Melalui Ombusman Law, Jurnal.

BidangHukumInfoSingkat,KajianSingkatTerhadapIs uAktualdanStrategis

VolXINo.23/I/Puslit/Desember/2019:1)

${ }^{4}$ Andi Saputra, http://news.detik.com/berita/d4756789/mengenal-omnibuslaw-revolusi-hukumyang-digaungkan-jokowi).
}

negara, terutama yang menggunakan tradisi Common Law System, sedangkan Indonesia mewarisi tradisiCivil Law System.

Tradisi sistem hukum saat ini sudah tidak terlalu ketat dan dikotomis, namun pembentukan Omnibus Law tetap perlu memperhatikan ketentuan pembentukan bundang-undang di Indonesia. Setidaknya terdapat 3 (tiga) tantangan untuk penerapan Omnibus Law diIndonesia, yaitu :

1) masalah teknik perundang-undangan;

2) penerapan asas peraturan perundang-undangan;

3) potensi terjadinya resentralisasi kewenangan .

Novianto Murti Hantoro ${ }^{5}$ Hal ini karena penerapannya dikhawatirkan akan menggangu system ketatanegaraan yang dianut Indonesia yang lebih banyak menganut system Civil Law dan ada kekhawatiran akan bertentangan dengan UUNo.12 Tahun 2011 tentang Pembentukan Peraturan Perundang Undangan yang diubah dengan UU No. 15 Tahun 2019 tentang Perubahan atas UU No. 12 Tahun 2011 karena secara teori perundang-undangan di Indonesia, kedudukan UUdari konsep Omnibus Law belum diatur, dimana konsep Omnibus Law mengarah sebagai UU payung yang mengatur keseluruhan yang kemudian mempunyai kekuatan terhadap aturan lain. Oleh karenanya menarik untuk dilakukan penelitian lebih lanjut mengenai apakah sebagai UU paying Omnibus Law selaras dengan UU No12 tahun 2011 tersebut.

\section{B. Permasalahan}

Dalam penelitian ini,peneliti akan mencoba untuk menjawab permasalahan yang peneliti angkat yaitu mengenai bagaimanakah peningkatan pembangunan ekono

\footnotetext{
5 AgusDarmawan, Politik Hukum Omnibus Law Dalam KonteksPembangunan EkonomiIndonesia, IndonesianJournalofLawandPolicyStudies Volume1 No.1Mei2020, Jakarta, hlm. 1
} 
mi di Indonesia melalui politik hukum omnibus law?

\section{Pembahasan}

Salah satu tujuan pemerintah menggulirkan Omnibus Law yaitu mendorong investasi, dimana kebijakan ini untuk mengejar visi Indonesia 2045 untuk menjadi 5 kekuatan besar ekonomi dunia, yang dalam Pidatonya Presiden Jokowi pada Pelantikannya pada siding Paripurna mengatakan:

a) Indonesia keluar dari jebakan pendapatan kelas menengah dan Indonesia telah menjadi Negara maju;

b) Produk Domestik Bruto Indonesia mencapai 7 triliun dollar AS dan Indonesia sudah masuk 5 besar ekonomi dunia dengan kemiskinan mendekati nol persen. Untuk mencapai hal tersebut, arahan Presiden 5 tahun kedepan yang akan dikerjakan antara lain: ${ }^{6}$

1) Membangun SDM yang pekerja keras, yang dinamis.

2) Pemerintah akan mengajak DPR untuk menerbitkan Undang-Undang Cipta Lapangan Kerja yang menjadi Omnibus Law yang merevisi puluhan unda-ngundang yang menghambat penciptaan lapangan kerja dan yang menghambat pengembangan UMKM.

3) Investasi untuk penciptaan lapangan kerja harus diprioritaskan dan prosedur yang Panjang harus dipotong.

Berdasarkan laporan Doing Business in Asia (2016)Indonesia tercatat sebagai salah satu Negara di Asia yang sistem hukum dan perundang-undangannya terkenal sangat birokratis sekaligus koruptif bagi parainvestor local terutama asing. Halter sebut diperparah dengan masih banyaknya kontradiksi dan disharmoni perundang-undang baik horizontal maupun vertikal. Sistem

\footnotetext{
${ }^{6}$ Kementrian Koordinator Bidang Perekonomian Republik Indonesia, Omnibus Law, Kementrian Koordinator Bidang Perekonomian Republik Indonesia, Jakarta 2020, hlm.3-4.
}

perundang-undangan alih-alih ringkas, padat, jelas, malah menderita "obesitas" sehingga lamban bergerak memberi legitimasi. Hal tersebut berakibat pada lunturnya marwah kepastian hukum berinvestasi di Indonesia.

Politik hukum diartikan sebagai kebijakan dasar penyelenggara negara dalam bidanghukum yang akan, sedang dan telah berlaku, yang bersumber dari nilai-nilai yang berlakudi masyarakat untuk mencapai tujuan negara yang dicita-citakan. Tujuan dari politik hukum nasional adalah sebagai alat (tool) atau sarana dan langkah yang dapat digunakan oleh pemerintah untuk menciptakan suatu sistem hukum nasionalyang dikehendaki dan dengan sistem hukum nasional itu akan diwujudkan citacita bangsaIndonesiayang lebih besar.

Pada tataran empiris, Moh. Mahfud MD mempergunakan politik hukum sebagai pendekatan dalam memahami relasi antara hukum dan politik, serta mendefinisikan politik hukum sebagai arah kebijakan hukum (legal policy) yang di buat secara resmi oleh Negara tentang hukum yang akan diberlakukan atau tidak akan diberlakukan untuk mencapaitujuan negara. Hukum ditempatkan sebagai alat untuk mencapai tujuan negara sehingga pembuatan hukum baru atau pencabutan hukum lama oleh Negara harus dijadikan langkah untuk mencapai tujuan negara. Menurut Pablo Holmes, ${ }^{8}$ politik dan hukum harus memiliki korelasi yang sejalan namun bukan sebagai instrument untuk mendukung kemauan eksekutif atau pemerintah yang sedang berkuasa.)

Salah satu tujuan Negara yang dimuat dalam Pembukaan UUD 1945 adalah tercapainya kesejahteraan masyarakat Indonesia. Untuk itu, pondasi perekonomian Indonesia perlu diperkuat salah satunya

\footnotetext{
${ }^{7}$ Mirza Satria Buana,
}

https://news.detik.com/d-4858165/mencarirumusan-ideal-omnibus-law-indonesia. diakses pada tanggal 30 April 2020.

${ }^{8}$ Ibid 
dengan cara menarik investor untuk sebesar-besarnya berinvestasi di Indonesia. Masuknya investasi di Indonesia diharapkan akan mendorong penciptaan lapangan kerja yang seluas-luasnya untuk seluruh rakyat Indonesia. Perlu adanya inovasi dari Pemerintah untuk menarik investor, salah satunya melalui penyederhanaan dan perampingan peraturan atau yang kita kenal sebagaiOmnibus Law.

Omnibus Law /RUU Cipta Kerja yang saat disusun Pemerintah menjadi program unggulan Pemerintahan JokowiMa'ruf Amin demi menggenjot partumbuhan eko-nomi danmasuk dalam Prolegnas Prioritas 2020. Sejumlah kalangan mengkritik pembentukan Omnibus law ini dengan beragam alasan dan argumentasi terkait metode penyusunan satu regulasi (UU) baru sekaligus menggantikan/ menghapus beberapa pasal dalam satu regulasi atau lebih yang berlaku. Namun demikian, tidak sedikit kalangan mendukung pembentukan Omnibus Law ini sebagai salah satu strategi reformasi regulasi mengatasi kondisio besitas/ hiper regulasi, khususnya disektor kemudahan berusaha.

Politik hukum omnibus law diharapkan memberikan lima manfaat bagi perekonomian Indonesia umtuk meningkatkan dan dalam rangka pembangunan ekonomi Indonesia yakni: ${ }^{9}$

1) pertama, penciptaan lapangan kerja yang diproyeksikan sebanyak $2,7-3$ juta per tahun.

2) Kedua, peningkatan kompetensi pencari kerja dan kesejahteraan pekerja.

3) Ketiga, peningkatan produktivitas pekerja, yang berpengaruh pada peningkatan investasi dan pertumbuhan ekonomi.

4) Keempat, peningkatan investasi

${ }^{9}$ Sony Hendra Permana, proyeksi dampak omnibus law undang-undang ciptakerja ter hadap ekonomi indonesia, Puslid BKD, Volume XII, no, 19/I/Puslid/2020, Jakarta, 2020, hlm. 20. yang diproyeksikan sebesar 6,6$7,0 \%$ untuk membangun usaha baru atau mengembangkan usaha existing yang akan menciptakan lapangan kerja baru dan meningkatkan kesejahteraan pekerja sehingga akan mendorong peningkatan konsumsi $(5,4-5,6 \%)$.

5) Kelima, pemberdayaan UMKM dan koperasi, yang mendukung peningkatan kontribusi UMKM terhadap PDB yang diperkirakan menjadi $65 \%$ dan peningkatan kontribusi koperasi terhadap PDB menjadi 5,5\% (ekonomi.bisnis.com, 7 Oktober 2020).

Salah satu sector yang akan terimbas langsung dengana dan ya undangundang ini adalah sector konstruksi dan properti. Adanya investasi baru akan meningkatkan permintaan terhadap lahan usaha. Selain itu pembangunan pabrik dan infrastruktur pendukung juga akan meningkatkan permintaan jasa perusahaan konstruksi. Dengana dan ya pembangunan pabrik didaerah tertentu seperti dikawasan industry baru atau kawasan ekonomi khusus, juga akan meningkatkan permintaan rumah bagi pekerja yang membutuhkan hunian (Media Indonesia,7 Oktober 2020).

Sektor ekonomi lainnya yang juga akan terpengaruh langsung adalah sector UMKM. Khusus bagi sector UMKM, manfaat yang diharapkan dapat diterima dari pengesahan UU ini adalah: pertama, kemudahan dan kepastian dalam proses perizinan melalui Online Single Submission (OSS). Kedua, kepastian legalitas bagi pelaku usaha UMKM melalui kemudahan dalam mendaftarkan Hak Kekayaan Intelektual (HAKI), kemudahan dalam mendirikan Perseroan Terbuka (PT) perseorangan, dan kemudahan persyaratan legalitaslainnya dengan biaya yang murah. Ketiga, menjamin percepatan dan kepastian dalam proses sertifikasi halal, bahkan khusus untuk usaha mikro 
dan kecil (UMK) biaya sertifikasi ditanggung oleh pemerintah.

Pengesahan UU Cipta Kerja ini juga memberikan dampak yang positif terhadap pasar keuangan. Indeks Harga Saham Gabungan (IHSG) Bursa Efek Indonesia (BEI) pada perdagangan hari Selasa tanggal 6 Oktober 2020 ditutup menguat 40,45 poin atau $0,82 \%$ keposisi 4.999,22. Sementara itu kelompok 45 saham unggulan atau indeks LQ 45 bergerak naik 9,08 poin atau $1,2 \%$ menjadi 764,16 (Media Indonesia, 7 Oktober 2020). Selain itu, pengesahan undang-undang ini juga berdampak positif terhadap nilai tukar rupiah, dimana pada perdagangan hari yang sama, nilai tukar rupiah ditutup menguat 65 poin atau $0,44 \%$ keposisi Rp14.735 perdolar AS. PenguataninimerupakanyangterbesardiAsiayang diikutiolehnilai yuan China dan baht Thailand yang menguat masing-masing sebesar $0,37 \%$ dan $0,36 \%$ (Bisnis Indonesia, 7 Oktober 2020).

Menurut penulis pembentukan omnibus law sebenarnya juga berdampak negatif terhadap pembangunan ekonomi Indonesia, antara lain merugikan pekerja, merugikan bidang pertanian, mereduksi konsep administrasi pendidikan yang pada dasarnya berorientasi pasar menjadi berdaya saing termasuk di dalamnya kurangnya transparansi. Pekerja sering merasa terbebani dikarenakan perpanjangan jam kerja dan lembur, rendahnya penetapan upah minimum yang dapat menyebabkan pelanggaran hak serikat pekerja, dan juga hilangnya hak-hak pekerja perempuan.

Omnibus Law sebagai konsep hukum dapat memberikan kontribusi dan pengaruh yang besar untuk meningkatkan investasi dan pengembangan ekonomi Indonesia apabila terdapat unsur prediktibilitas, kemampuan procedural, kodifikasi tujuan, factor penyeimbangan, akomodasi, dan definisi dan kejernihan tentang status sebagaimana disampaikan oleh ahli hukum J.D. Ny Hart.

Menurut pemikiran J.D. Ny Hart terdapat enam konsep dalam ilmu hukum yangmempunyai pengaruh bagi

pengembangan ekonomi,yaitu:

a. Prediktabilitas, bahwa hukum harus mempunyai kemampuan untuk memberikan gambaran pasti dimasa depan mengenai keadaan atau hubungan-hubungan yang dilakukan padamasa sekarang;

b. Kemampuan procedural, bahwa pembinaan dibidang hukum acara memungkinkan hukum material itu dapat merealisasikan dirinya denganbaik ke dalam pengertian hukum acara ini termasuk tidak hanya ketentuanketentuan hukum perundang-undangan, melainkan juga semua prosedurpenyelesaian yang disetujui oleh para pihak yang bersengketa, misalnyabentukbentuk arbitrasi, konsiliasi, dan sebagainya;

c. Kodifikasi tujuan-tujuan, bahwa perundang-undangan dapat dilihat sebagai suatu kodifikasi tujuan serta maksud sebagaimana dikehendaki oleh negara. Misalnya di bidang ekonomi, kita akan dapat menjumpai tujuan-tujuan ituseperti dirumuskan di dalam beberapa perundang-undangan yang secara langsung atau tidak langsung mempunyai pengaruh terhadap bidang perekonomian;

d. Faktor penyeimbangan, bahwa sistem hukum harus dapat menjadi kekuatan yang memberikan keseimbangan di antara nilai-nilai yang bertentangan didalam masyarakat. Sistem hukum memberikan "kesadaran akan keseimbangan"dalam usaha-usaha negara melakukan pembangunan ekonomi;

e. Akomodasi, bahwa perubahan yang cepat sekali pada hakikatnya akan menyebabkan hilangnya keseimbangan yang lama, baik dalam hubungan antar individu maupun kelompok didalam masyarakat. 
Sistem hukum memberikan pegangan kepastian melalui perumusan-perumusan yang jelas dan definitive, membuka kesempatan bagi dipulihkannya keadilan melalui prosedur yang tertib dan sebagainya; dan

f.Definisi dan kejernihan tentang status. Bahwa fungsi hukum memberikan ketegasan mengenai status orang-orang dan barang-barang dimasyarakat. ${ }^{10}$

Omnibus law dapat berperan efektif mengurangi disharmonisasi dan konflik norma dalam perundangan-undangan, namun disisi lain juga memiliki legitimasi demokratis yang akuntabel lewat mekanisme uji publik dan partisipasi publik yang luas dan dilakukan dengan prinsip kehati-hatian.Guna menjamin prinsip kehati-hatian dalam perumusan perundanganundangan, maka Omnibus Law harus dirumuskan dengan terlebih dulu melakukan upaya konsolidasi norma-norma, definisi-definisi konseptual, dan menetapkan subjek yang akan menjalankan undangundang Omnibus Law tersebut.

Terobosan Pemerintah dengan menginisiasi Omnibus Lawakan efektif apabila mendasarkan pada asas-asas perundanganundangan yang bersemangat rule of law serta taat pada nilai-nilai dan kepentingankepentingan kemanusiaan yang berkelanjutan. Advokasi dari seluruh elemen bangsa dalam tataran perumusan dan implementasi Omnibus Law akan mampu mewujudkan peningkatan investasi di Indonesia yang pada akhirnya akan mewujudkan kesejahteraan bagi seluruh rakyatIndonesia.

Dalam penerapan Omnibus Law, pencabutan aturan harus dilakukan secara cermat. Ketentuan penutup dari Omnibus Law harus menegaskan soal pencabutan pasal-pasal dari undang-undang terdampak agar tidak menimbulkan perdebatan konflik norma hukum.

Hal lain yang juga perlu menjadi

\footnotetext{
${ }^{10}$ Rahardjo,Hukum dan Masyarakat,
} Angkasa, Bandung, 1980,hlm. 34. perhatian adalah bahwa setiap undangundang memiliki dasar filosofis, sosiologis, dan yuridis yang berbeda, sehingga pertimbangan aspek filosofis, sosiologis, yuridis aturan yang akan dicabut harus dilakukan secara cermat, khususnya yang menyangkut hak konstitusional warga negara.

Identifikasi persoalan juga harus dilakukan secara cermat. Pengubahan atau pencabutan sebaiknya dilakukan pada tataran substansi hukum, sedangkan pada tataran aspek penerapan atau budaya hukum masyarakat yang diperlukan adalah perubahan implementasi kebijakan.

Omnibus Law secara teoritis dapat menjadi solusi atas konflik peraturan perundang-undangan secara cepat, efektif, dan efisien. Namun demikian, perlu memperhatikan asas dalam peraturan perundangundangan Indonesia yaitu asas lexposterior derogat legi priori (Undang-undang yang disahkan belakangan akan tetap bisa mengesampingkan omnibus law jika materi muatannya berbeda). Perlu harmonisasi secara hati-hati tidak hanya pada undangundang yang akand icabut dengan omnibus law, namun demikian dengan Rancangan Undang Undang (RUU) lain yang sedang dibahas, sehingga Peraturan Pemerintah Pengganti Undang-Undang (Perppu) bisa jadi opsi bentuk Omnibus Law.

Omnibus Law sebagai konsep pembaharuan hukum untuk meningkatkan investasi di Indonesia yang disampaikan dalam tulisan ini harus bergerak dari sistempenyusunan peraturan perundangundangan yang ada.Proses Omnibus Law harus memperhatikan aspek yuridis, politik, sosiologi dan ekonomi.Dalam konteks yuridis,sistem perundang-undangan harus berimbang dalam aspek efektivitas dan akuntabilitas.

\section{Kesimpulan}

Omnibus Law sebagai upaya Pemerintah dalam meningkatkan pembangunan ekonomi di Indonesia dan meningkatkan kesejahteraan seluruh rakyat 
Indonesia dalam perumusan maupun implementasinya harus berimbang dalam tataran efektivitas dan akuntabilitas dengan memperhatikan aspek yuridis, politik, sosiologi dan ekonomi.

\section{DAFTAR PUSTAKA}

Agus Darmawan, Politik Hukum Omnibus Law Dalam Konteks Pembangunan Ekonomi Indonesia, Indonesian Journal of Law and Policy Studies Volume 1 No.1 Mei 2020, Jakarta.

Andi Saputra, http://news.detik.com/berita/d-4756789/mengenal-omnibuslaw-revolusi-hukum-yangdigaungkan-jokowi).

Dhaniswara K. Harjono, Konsep Omnibus Law Ditinjau Dari Undang-Undang No.12 Tahun 2011 Tentang Pembentukan Peraturan Perundang Undangan, Jurnal Hukum : Hukum Untuk Mengatur Dan Melindungi Masyarakat, Fakultas Hukum Universitas Kristen Indonesia, Jakarta, 2020.

Kementrian Koordinator Bidang Perekonomian Republik Indonesia, Omnibus Law , Kementrian Koordinator Bidang Perekonomian Republik Indonesia, Jakarta 2020.

Mirza Satria Buana, https://news.detik.com/d-4858165/mencari-rumusan-ideal-omnibus-law-indonesia. diakses pada tanggal 30 April 2020

Rahardjo, Hukum dan Masyarakat, Angkasa, Bandung, 1980.

Sulasi Rongiyati, Menata Regulasi Pemberdayaan UMKM Melalui Ombusman Law, Jurnal. Bidang Hukum Info Singkat, Kajian Singkat Terhadap Isu Aktual dan Strategis VolXINo.23/I/Puslit/Desember/2019:1)

Sony Hendra Permana, proyeksidampakomnibuslawundang-undangciptakerjaterhadapekonomiindonesia Puslid BKD, Volume XII, no, 19/I/Puslid/2020, Jakarta, 2020. https://kompas.com/tren/read/2019/10/22/apa-itu-omnibus-law.diakses pada tanggal 30 April 2021 
Lex Librum : Jurnal Ilmu Hukum, Vol. 7 No 2, Juni 2021, hal. 175-182 